\title{
The Impact of Human Resource Management Practices of the Managers on Perceived Organizational Performance-A Study on Ceylon Fisheries Corporation in Sri Lanka
}

\author{
Nilan Miranda' ${ }^{1}$, W. R. P. K. Fernando ${ }^{2}$ \\ ${ }^{1}$ Business Administration, University of Kelaniya, Kelaniya, Sri Lanka \\ ${ }^{2}$ Department of Commerce and financial Management, University of Kelaniya, Kelaniya, Sri Lanka \\ Email: nilanmiranda@gmail.com
}

How to cite this paper: Miranda, N. and Fernando, W.R.P.K. (2020) The Impact of Human Resource Management Practices of the Managers on Perceived Organizational Performance-A Study on Ceylon Fisheries Corporation in Sri Lanka. Open Access Library Journal, 7: e7034.

https://doi.org/10.4236/oalib.1107034

Received: November 25, 2020

Accepted: December 28, 2020

Published: December 31, 2020

Copyright $\odot 2020$ by author(s) and Open Access Library Inc.

This work is licensed under the Creative Commons Attribution International License (CC BY 4.0).

http://creativecommons.org/licenses/by/4.0/

\begin{abstract}
This study is significant to examine the impact of Human Resource Management Practices (HRMP) of the managers on Perceived Organizational Performance (POP). Employees in Managerial category at Ceylon Fisheries Corporation (CFC) in Sri Lanka totaling 123 responded for the survey. The survey questionnaire had comprised with 67 items enveloping selected HRMP and POP of CFC. This study has established that selected HRMP such as recruitment \& selection, training \& development, performance appraisal and reward management has a significant impact on POP in the context of CFC in Sri Lanka. The study utilized quantitative method and cross sectional approach. The results were derived from the survey study at the convenience of the researcher with quantitative approach. It is found that CFC has enhanced its performance to higher degree, by emphasizing more on proper recruitment $\&$ selection procedure, implementing comprehensive training \& development programs, application of sound performance appraisal system and execution of effective reward management initiatives. More studies on impact of HRMP on POP have focused on private sectors in Sri Lanka. Hence, this study has attempted to investigate the impact of HRMP on POP in CFC as an element of State-Owned Business Enterprises (SOBEs) in Sri Lanka.
\end{abstract}

\section{Subject Areas}

Sociology

\section{Keywords}

Human Resource Management Practices, Perceived Organizational 
Performance, Ceylon Fisheries Corporation

\section{Introduction}

Human Resource Management (HRM) is a discipline, a professional specialization that has developed in recent years as a broad spectrum of management, encompassing various field incorporated and synthesis with certain element of personnel management organizational behavior industrial and labor relationship and so on. HRM is defined as a strategic, integrated and coherent approach to the employment, development and well-being of the employees in respective organizations (Armstrong, 2010) [1]. HRM links with all the management decisions, actions and directions which affect the nature of the relationship between the employee and employer in respective organization (Beer et al., 1984) [2]. Guest, (1987) [3] explained that HRM comprises a set of policies and procedures designed to maximize organizational integration, commitment of employees attached, flexibility and quality of work performed by employees. HRM is "The management of work and people towards the desired ends" (Boxall, 2007) [4]. HRM is concerned with the means and ways of managing the workforce by their organization (Grimshow and Rubery, 2007) [5]. Redman, and Wilkinson, (2001) [6], elaborated that HRM policies are to be entangled with strategic business planning of the organization in order to achieve the organization's excellence, through the committed workforce. Thus, organizational culture should be paid attention to value the human resources as a source of competitive advantage which they should be tapped by the consistent policies effectively to commit the employees' willingness to act flexibility in the interest of the organization. According to Storey, (2007) [7] HRM is considered as an exceptional approach to employment management which desires to achieve competitive advantage through the strategic deployment of capable, committed and entrusted workforce using an integrated disposition of structural, cultural and personnel techniques. HRM is the policies, procedures and systems that influence employees' behavior, attitudes, abilities and performance. HRM is defined as a series of integrated decisions on the employment relationship in an organization that influenced the effectiveness of employees as well as the organizations (US Army War College, 2007) [8].

Therefore, human resources have been identified as the most important asset of an organization. It forms a greater and reasonable portion of organization's resources and directly connects to the success of an organization.

HRMP are dealt with all the aspects of how people are employed and managed in particular organization. It has a strong conceptual basis drawn from the behavioral sciences, strategic management, human capital and industrial relations theories. This foundation has been built with the aid of a multitude of research studies (Armstrong, 2010) [1]. Most of the organizations refer to HRM as involving people practices. There are significant HRMP that should engage the 
organization's business strategy such as analyzing of work and designing of jobs, determining how many employees with specific knowledge and skills are needed (human resource planning), attracting potential employees (recruiting), choosing employees (selection), educating employees how to perform their jobs and preparing them for the future (training \& development), evaluating their performance (performance management), rewarding employees (compensation) and creating a positive and healthy work environment (employee relations). An organization performs utmost when all of these practices are managed well. Organizations with effective HRMP, employees and customers apt to be more satisfied and the organizations apt to be more innovative, have a greater productivity developing a more beneficial identity in the community of employee (Noe, et al., 2003) [9]. According to Dessler, (2007) [10] HRMPs include selecting human resource needs, screening, recruiting, training, rewarding, appraising, attending to labor relations, safety and health. Management of an organization can reach the goals and objectives of human resources through the contribution (behavior), composition (ratio and skill), competence (ability) and commitment (attachment and identification) (Dyer and Holder, 1998) [11].

Organizational Performance (OP) being an indicator which measures the degree an enterprise achieves their goals and objectives (Hamon, 2003) [12]. According to Delaney and Huselid, (1996) [13], OP is concerned as product or service quality, product or service innovation, attraction of employees, management of employees, retention of employees, customer satisfaction, interaction between management and employees and employee relation. Bontis, (2001) [14] states that the human elements of an organization are capable of learning, changing, innovating and providing the thrust with motivate properly and ensure the organization's sustainability. Delery, (1998) [15] identified the methods used by an organization to manage its workforce, having a substantial impact on many organizationally relevant outcomes. When organizations face any challenges such as an economy recession, market turbulences, it depends mainly on trained employees who react immediately to changes in the environment and create new strategies to overcome the problems and achieve the success. Organization should prioritize the development of the human element to maximize talents, skills and ability which will automatically reflect on the organization's profit as the organizations need people in order to form a business which that no business can exist entirely without people. Opatha, (2012) [16] states that all the other resources are collected, combined and used only by HR, through making decision. In fact other resources make things possible but only $\mathrm{HR}$ makes things happen. The term HR implies that people have ability and capability to drive organizations towards the success with the interaction of the other resources. Further explains that an effective HRMP enables employees to contribute effectively and productivity to the overall organizational direction and the accomplishment of the organization's goals and objectives. OP measures how well an organization function and also an indication of efficiency and competition of a single or department. In accordance with the considerations of 
Thompson (1967), and Friedlander and Pickle (1968) [17], OP is defined as the evaluation of the elements that attempt to assess the abilities and capabilities of an organization to achieve such components' desire level with effectiveness and efficiency. OP is insistent by measuring the actual outputs of an organization against its intended outputs like the organizational goals or objectives. According to Richard (2009) [18], OP comprises with three areas of company outcomes such as financial performance (return on assets, return on investment, profits), product market performance (sales and market share) and shareholder return. OP refers to strategic planning, operations, finance, legal and organization developments. Some researchers relate $\mathrm{OP}$ as financial performance, which involves budgets, assets, operations, products, services, and markets (Thurbin, 1994 [19]; Subramaniam, Shamsudin, \& Ibrahim, 2011 [20]). Some researchers identify several non-financial outputs which also contribute to OP, as management quality (De Waal and Frijns, 2011) [21] long-term orientation (Steiss, 2003 [22]; Guest, 2002 [23]), continuous improvement (Arsad, 2012) [24], workforce quality and openness and action orientation (Storey, 1989) [7]. According to Collins, and Smith, (2006) [25] the effective implementation of HRMP in organizations is a key source of competitive advantage and it has a positive relationship with OP.

State owned business enterprises are representing crucial sectors of the economy of Sri Lanka having recorded Rs 175,555 billion turn over which is almost 13.22 percent of the GDP in 2017. In fact, the return on assets amounting to only 0.64 percent of the 55 SOBEs. It is evidence that SOBEs have not been performing to its entire potential. The government strategy is to encourage and facilitate the SOBEs to be self-sufficient through improved corporate practices, management reforms, innovative financing and prudent financial management, exposure to competitiveness and international best practices and specifically an effective HRM (Ministry of Finance 2018) [*]. Hence, being the state owned organizations, SOBEs in Sri Lanka need to attract, develop and retain their employees in order to achieve the ultimate objectives defined. They require competent employees who are trained and motivated in order to reach the organizational success. Implementation of appropriate HRMP for SOBEs employees will promote OP in respective organizations. Therefore, considering the significance of the factors, this research is focused to examine the impact of HRMP on POP in the context of Ceylon Fisheries Corporation in Sri Lanka being a State Owned Business Enterprise (SOBE).

The objectives of the study are as follows:

- To determine the relationship between HRMP and POP of CFC

- To examine the impact of HRMP on POP of CFC

- To identify the measures to enhance the CFC's performance

- To assess the effective Human Resource Management Practice strategies to enhance the Organizational Performance of CFC.

The limitations of the study have been identified as, the study focused the evidence for the study from CFC in Sri Lanka. The study further limited to four 
factors of HRMP as the independent variables in this study, recruitment \& selection, training \& development, performance appraisal and reward management and the dependent variable was perceived organization performance. Also in this study the sample was drawn only from the higher, middle and junior level managers and the correlation study have been employed. Thus the data collection was done as cross sectional approach.

\section{Statement of the Problem}

The impact of HRMP on OP has been a broadly researched area. Either developed countries or developing countries the result of studies, have been showing that HRMPs have significant impact on OP. However, there are no studies have been carried out in this context of Sri Lanka and even in the developed countries insufficient amount of studies have been conducted especially in the context of state owned organizations. This study assessed the impact of HRMP on POP and investigates the influence of CFC's four HRMPs such as recruitment \& selection, training \& development, performance appraisal and reward management on POP. Even though, it was accepted that HRMP are positively related to OP in different contexts, there is a great need for additional evidence to support the relationship of HRMP and POP in different contexts.

The observations of the researcher in CFC, the staff criticize the HRMP in placed. Especially, they are not satisfied with their wellbeing in terms of rewards such as salary, wages and benefits. Thus, they are unfamiliar on the performance evaluation process. The way of absorbing employees into the organization and the means available for them to enhance their skills and knowledge are not in the due degree of the implementation. Due to these negative practices, talented employees of state owned organizations have been moved to private sector or other countries. There are no significant and or comprehensive practices in placed at public organizations' HRM department. The main cause of that is the top management never realizes the importance of HRM and needs and wants of their employees. In order to develop a better understanding, this research is carried out to identify the benefits from HRMP towards the OP. Sri Lanka being a country in the growing phase needs to know the contribution of different factors and the intensity of their impact on OP that leads towards economic development of SOBEs and onward benefit to the country. Therefore, it is important to determine empirically, the contribution of different factors not other than, HRMP towards POP.

\section{Hypotheses}

Five hypotheses have been developed for the study on the foundation of substantial literature review and mentioned below,

- Hypothesis 1: HRMP have significant impact on POP

- Hypothesis 2: Recruitment \& Selection have positive impact on POP

- Hypothesis 3: Training \& Development have positive impact on POP 
- Hypothesis 4: Performance Appraisal has positive impact on POP

- Hypothesis 5: Rewards Management has positive impact on POP

\section{Methodology}

A research method is explained simply as a technique for collecting data. Research methodology is defined as a systematic approach or a procedure of studying a research phenomenon (Kothari, 2011) [26].

\section{Research Design}

There are two main approaches to research study, the quantitative approach and the qualitative approach, both methods have advantages and disadvantages; neither of them is wrong or right but each may be more or less useful for specific research purposes (Kothari, 2011) [26]. The choice of a particular method depends on the nature of the research and objectives of the study, which determines the selection of the research methods i.e. qualitative, quantitative or mixed methodology (Kothari, 2011) [26]. The strengths and weaknesses of the mixed-methods design have been broadly discussed and understood. (Creswell, Goodchild, and Turner 1996 [27]; Tashakkori, and Teddlie, 2010 [28]; Creswell 2014 [29]). They stated that the basic aim of mixed method research is to combine these two research methods in a way to consider the strengths and weaknesses of each method by enhancing the strengths and eliminating the weaknesses. The design related with this study is quantitative approach. The rationale behind this approach is that the quantitative data and subsequent analysis provide a general understanding of the research.

Moses (2014) [30] stressed in his study that a correlation research is a quantitative in nature and two or more variables are taken into consideration in order to determine the relationship. Also correlation research can be utilized to measure and or determine the nature and degree of the variables. In this study, used confirmatory correlation research design as the researcher wanted to establish the relationships between closely connected variables, to employ deductive approach and to test the hypothesis developed in this study context. Based on the aforementioned literature, this study adopted a comprehensive research design in order to achieve the aim and objectives of the study (Tashakkori and Teddlie, 2010 [28]; Creswell, 2014 [29]).

Therefore, the study utilized a relational research design in an effort to examine the relationship between HRMP and POP. Correlation research methods are used to determine relationships and patterns of relationships among variables in a single group of subjects. In correlation studies a researcher may be able to state a hypothesis about an expected relationship. If two variables are correlated, then one variable can be used to predict the other. Four HRMP considered as independent variables in this study were recruitment \& selection, training \& development, performance appraisal and reward management whereas, POP was the dependent variable. The research methodology was based on empirical data collected through questionnaire surveys with the managerial level employees in CFC. 


\section{Population}

Population is considered as a group of individuals, objects or items among which samples are drawn for measurement (Singh, 2007) [31]. The population includes entire members of elaborated group of people, events or objects (Ary, et al. 2006) [32]. Sekaran and Bougie (2016) [33] defined the population as the entire group of people, events or things of interest that the researcher wishes to investigate. The target population for this study was the employees of CFC. This includes all employees in higher, middle and junior level management attached to various regions in island wide and different departments of CFC. The target population for this study was 1203 who were born in the books of the organization inclusive permanent, temporary and daily payment cadres during the period of the study from January 2019 to June 2019.

\section{Sampling and Sampling Technique}

The sample for this study was 123 employees selecting from the staff categories of higher managers (5), middle managers (65) and junior managers (53) representing all the regions and departments of CFC. Stratified random sampling technique was used in this study. The total numbers of the workers were 1203 and out of that 534 in managerial categories. The researcher selected all the higher level managers, all the middle level managers and $20 \%$ of junior level managers totaling 123. A total of 123 questionnaires were distributed among them and collected all with the duly perfected.

\section{Data Sources and Instrumentation}

This study was based on primarily obtained sources of data. In order to collect the data a structured questionnaire was distributed among the respondents. The questionnaires were distributed to the respondents by the researcher at the common place at CFC head office premises by attending personally. Therefore, the researcher was able to collect the majority of duly perfected questionnaires since the doubts and clarifications were addressed and sorted out during the session of the response. Therefore, the response rate was great.

\section{Survey Instrument}

The questionnaire used in this study was divided into three main sections. The first section of the questionnaire gathered information on the profile of respondents. The profiling variables were comprised with five questions such as age, gender, education qualification, employment category, length of service. This was placed at the beginning of the questionnaire in accordance with the on the recommendations of Sekaran and Bougie, (2014) [34] suggested that, in designing the questionnaire; the personal information should be asked at the beginning or at the end of the survey instrument. The second section of the questionnaire measures the extent to HRMP (recruitment \& selection, training \& development, 
performance appraisal and reward management) are being practiced in CFC. The third section of the questionnaire measures the CFC's performance. Respondents are requested to rate those second and third sections based on five-point $\mathrm{Li}$ kert scale ranging from $1=$ strongly disagree, $2=$ disagree, $3=$ neutral, $4=$ agree and $5=$ strongly agree.

\section{Survey Language}

The questionnaire wording, types, forms and systematic flow play a major role in keeping respondents interested until at the end of the questionnaire (Sekaran, 2000) [35]. Zikmund, (2010) [36] argued that closed ended questions are comparatively preferred than the open ended questions for quantitative research due to less time for response and easy to coding and tabulating purposes. Bryman and Bell, (2015) [37] explained the advantages of the selection of closed ended questions with a vertical format. Also stated that closed ended questions can be pre coded, thus turning the processing of data for computer analysis into a fairly simple. This study chose close-ended questions for the quantitative analysis. The questionnaire was designed in Sinhala and English as the most of the employees are not competent enough to clearly understand the English which could be easy to use for researcher to analysis process. The questionnaire was written in simple and easy to understand language related to aforementioned HRMP and POP in CFC.

\section{Response Rate}

The data was collected in the month of June 2019. A total of 123 survey questionnaires were distributed. All the questionnaires were returned; a return rate of $100 \%(\mathrm{n}=123)$, from which $(\mathrm{n}=13) 10.56 \%$ questionnaires were discarded due to incompleteness and considerable number of missing values. Finally, $89.44 \%$ $(\mathrm{n}=110)$ completed questionnaires were used for the final analysis. A response rate of $89 \%$ is considered as the highly acceptable response rate for this study.

\section{Measurement}

\section{Human Resource Management Practices questionnaire}

In accordance with the studies of Tessema, Mussie \& Soeters, Joseph. (2006) [38]. Rehman (2012) [39], Dechawatanapaisal and Siengthai, (2006) [40], Djabatey (2012) [41] McGhee (1996) [42], Subramaniam et al. (2011) [20], 32 questions of HRMP were used for this study. This questionnaire comprised with recruitment \& selection (6), training \& development (8), performance appraisal (11) and reward management (7).

\section{Perceived Organizational Performance questionnaire}

In this study POP was measured by 11 questions following the studies of Delaney \& Huselid (1996) [13], Kim \& Kim, (2016) [43].

\section{Review of Literatures}

The review of literature witnessed that there have been several studies concen- 
trating on HRMP and OP in global concept. However, limited numbers of studies have been conducted on the impact of HRMP on OP in context of Sri Lanka and not found any studies with regard to POP as the dependable variable in the Sri Lankan context. Therefore, this study has been undertaken to bridge this obviously identified research gap.

\section{Data Analysis of the Study}

Data screening and data cleaning were conducted initially in order to obtain actual and quality results. The study stressed the response rate of the respondents and elaborated the description of demographic and organizational profiles of the respondents of the study. Questionnaires were coded and entered into SPSS 23 to process the needed calculations. Cronbach's alpha was calculated to determine the internal reliability of the tools. The confirmatory factor analysis for the study utilized as the primary tool to analyze construct validation.

SPSS can take data from any type of file and use the same to generate tabulated reports, charts and plots of distributions and trends, descriptive statistics, and complex statistical analyses. Construct validity of measures was determined for the validation of an instrument. For accurate relationship among variables, construct validity of measures is incredibly essential and it relies on the aptitude of the researcher to appropriately measure the variables. Cronbach's alpha was calculated to determine the internal reliability of the tools. Frequency distribution was used to describe the profile of the sample. After organizing the data into a frequency distribution, it's presented in graphical form. The purpose of graphs in statistics is to communicate the data to the viewers in pictorial forms. It is easier to comprehend the meaning of data presented in graphically than numerically in tables or frequency distributions. This is especially fruitful, when the users have little or no statistical knowledge. Finally regression analysis was performed. The $\mathrm{R}^{2}$ value was computed to examine the goodness predictive validity so that it can be used to predict the future behavior.

\section{Response Rate}

Out of the 123 sample respondents 110 successful respondents after screening and cleaning, have been used for analysis, making a response rate of $89 \%$. This response rate was excellent and conforms to Mugenda and Mugenda, (1999) [44] stipulation that a response rate of $50 \%$ is adequate for analysis and reporting, a rate of $60 \%$ is good and a response rate of $70 \%$ and over is excellent.

\section{Demographic Characteristics of the Respondents}

Frequencies of occurrence of certain variables are determined, from which the percentage and cumulative percentage are calculated. Frequency tables of demographic variables are shown bellow.

The simple majority of the respondents were male $(n=63)$ representing $57.3 \%$ of the sample, whereas female were $(n=47)$ representing $42.7 \%$ (Table 1$)$. 
Table 1. Gender of the respondent.

\begin{tabular}{ccccc}
\hline & & Frequency & Valid Percent & Cumulative Percent \\
\hline Valid & Male & 63 & 57.3 & 57.3 \\
& Female & 47 & 42.7 & 100 \\
& Total & 110 & 100 & \\
\hline
\end{tabular}

Source: Survey data.

Educational levels of the respondents have depicted in Table 2.

Majority of the employees have a Diploma ( $n=500$ representing $45.46 \%$ followed by a Bachelor's degree $(\mathrm{n}=33)$ representing $30 \%$, Certificate Level $(\mathrm{n}=$ 26) representing $23.63 \%$, and Master's $(n=1)$ representing $0.91 \%$.

The length of service of the respondents has shown in Table 3.

For the length of service period with the current employer, majority of respondents indicated that they had worked for three - four years $(n=40 ; 36.36 \%)$, followed by above the four years $(\mathrm{n}=31 ; 28.18 \%)$, two-three years $(\mathrm{n}=18$; $16.36 \%)$ and one-two years $(n=15 ; 13.64 \%)$, the smallest number of employees for less than one year $(n=06 ; 05.46 \%)$.

The age of the respondents has presented in Table 4.

For the age of the employees the majority of respondents mentioned that they are aged in $41-50$ years $(\mathrm{n}=40 ; 38.2 \%)$, followed by aged between $31-40$ years $(\mathrm{n}=33 ; 30 \%)$, aged between $21-30$ years $(\mathrm{n}=24 ; 21.8 \%)$ and the minority was aged between $51-60$ years $(n=11 ; 10 \%)$.

The employment category of the respondents has mentioned in Table 5.

For the employment category of the employees, the majority of respondents mentioned that they are serving as the middle level managers $(n=64 ; 58.2 \%)$, followed by junior level managers $(n=41 ; 37.3 \%)$. The lowest is higher level managers $(\mathrm{n}=05 ; 4.5 \%)$.

\section{Reliability and Validity}

A measurement is considered as reliable or consistent if the measurement can produce similar results when used again in similar circumstances. Analyzed results of the reliability of variables on HRMP and POP presented at under mentioned Table 6 with use of 32 and 11 items respectively. Accordingly, the value of alpha $(\alpha)$ is greater than $0.7(\alpha>0.7)$ in all the variables. HRMP shows the value of alpha is equal to $0.951(\mathrm{a}=0.951)$, POP value of alpha is equal to 0.883 $(\mathrm{a}=0.883)$. Hair et al., (2009) [45] explained that the alpha value should preferably be greater than 0.7 (a $>0.7)$ for reliability analysis. Thus, Cronbach value beyond seven $(a>7)$ signifies acceptable reliability (Kline 2016) [46]. Therefore, it was confirmed that the reliability of the measurement used for the study is within the accepted standard.

The internal consistency reliability of the measurers used in the study can be considered as good and reliable. It is observed that the scale of the present study was highly reliable for data analysis. Validation procedures involved initial 
Table 2. Educational levels of the respondents.

\begin{tabular}{ccccc}
\hline & & Frequency & Valid Percent & Cumulative Percent \\
\hline Valid & Certificate & 26 & 23.63 & 23.63 \\
& Diploma & 50 & 45.46 & 69.09 \\
Bachelor & 33 & 30.00 & 99.09 \\
Master & 01 & 00.91 & 100.00 \\
& Total & 110 & 100 & \\
\hline
\end{tabular}

Source: Survey data.

Table 3. Length of service in CFC.

\begin{tabular}{ccccc}
\hline & Frequency & Percent & Cumulative Percent \\
\hline Valid & Less than 1 year & 06 & 05.46 & 05.46 \\
1 - 2 years & 15 & 13.64 & 19.10 \\
2 - 3 years & 18 & 16.36 & 35.46 \\
3 - 4 years & 40 & 36.36 & 71.82 \\
Above 4 years & 31 & 28.18 & 100 \\
Total & 110 & 100 & \\
\hline
\end{tabular}

Source: Survey data.

Table 4. Ages of the respondents.

\begin{tabular}{ccccc}
\hline & & Frequency & Valid Percent & Cumulative Percent \\
\hline Valid & $21-30$ years & 24 & 21.8 & 21.8 \\
& $31-40$ years & 33 & 30.0 & 51.8 \\
& $41-50$ years & 42 & 38.2 & 90.0 \\
$51-60$ years & 11 & 10.0 & 100.00 \\
Total & 110 & 100 & \\
\hline
\end{tabular}

Source: Survey data.

Table 5. Employment categories of the respondents.

\begin{tabular}{ccccc}
\hline & Frequency & Valid Percent & Cumulative Percent \\
\hline \multirow{2}{*}{ Valid } & Junior Manager & 41 & 37.3 & 37.3 \\
& Middle Manager & 64 & 58.2 & 95.5 \\
& Higher Manager & 05 & 04.5 & 100 \\
& Total & 110 & 100 & \\
\hline
\end{tabular}

Source: Survey data.

Table 6. Reliability analyses of variables.

\begin{tabular}{ccc}
\hline Variable & No of Items & Alpha Value \\
\hline Human Resource Management Practices (HRMP) & 32 & 0.951 \\
Perceived Organizational Performance (POP) & 11 & 0.883 \\
Total & 43 \\
\hline
\end{tabular}


consultation of the questionnaires. Hence, researcher satisfied reliability and validity of the scales used.

The researcher analyzed the data obtained in this study by correlation and multiple regression analysis. In this context, a multiple regression was performed, by making use of all the discrete variables (i.e., dependent and independent variables) available in the dataset. The estimation process was based on Ordinary Least Squares (OLS) [i.e. $=a+b x]$. For this, purpose, the researcher consider the following model specifications, by taking POP as dependent variable and by making HRMP as independent variables.

$$
\mathrm{POP}=\beta_{0}+\beta_{1}(\mathrm{RNS})+\beta_{2}(\mathrm{TND})+\beta_{3}(\mathrm{PA})+\beta_{4}(\mathrm{RM})+e \cdots \text { Model }
$$

where $\beta_{0}, \beta_{1}, \beta_{2}, \beta_{3}$, and $\beta_{4}$, are the regression co-efficient.

POP: Perceived Organizational Performance, RNS: Recruitment and Selection, TND: Training and Development, PA: Performance Appraisal, RM: Reward Management and e: error term.

To test the mode- 1 fit the data and findings, correlation (r), R, $\mathrm{R}^{2}$ (Coefficient of determination), variance, and the $t$ test statistic were used. Correlation analysis was performed to find out the pair wise relationship between variables; RNS, TND, PA, RM, and POP.

A correlation result has shown in Table 5. Correlations amongst variables are positive. Correlation interpretation is based on following five classical rules introduced by Franzblau, (1985) $\left[{ }^{*}\right]$ to interpret correlation coefficient amongst different variables,

- $(r=0$ to 0.20$)$ indicates negligible or no correlation.

- $(r=0.20$ to 0.40$)$ indicates positive but low degree of correlation.

- $(r=0.40$ to 0.60$)$ indicates positive moderate degree of correlation.

- $(r=0.60$ to 0.80$)$ indicates positive and marked degree of correlation.

- $(r=0.80$ to .1 .00$)$ indicates positive and high degree of correlation.

All variables are treated symmetrically, i.e. there is no distinction between dependent variable and independent variables. Two variables are said to be correlated when they tend to simultaneously vary in the same direction. If both the variables tend to increase or decrease together, the correlation is said to be direct or positive. When one variable tends to increase and the other tends to decrease, the correlation is said to be negative.

Table 7 also shows that the factors RNS, TND, PA, and RM are independently andpositively correlated with POP and also highly significant at $1 \%$ levels. As a result, Hypothesis 1 of this study was accepted. The maximum correlation $(\mathrm{r}=$ $0.463)$ is existed between PA and POP, followed by the association $(r=0.456)$ between RM and POP; RNS and POP $(r=0.372)$; and TND and POP $(r=0.368)$. It should be needed to pay the highest emphasis on PA for greater POP. RM also crucial for magnificent POP followed by other HRMP (i.e., RNS and TND). HRMP are positively correlated with one to another and also statistically significant at P-value 0.000. Among the four HRMP, the relationship $(r=0.697)$ between PA and RM is the highest, followed by the relationship $(r=0.556)$ between TND and PA. 
Table 7. Correlations of variables.

\begin{tabular}{|c|c|c|c|c|c|c|}
\hline & & RNS & TND & PA & $\mathrm{RM}$ & $\mathrm{OP}$ \\
\hline \multirow[t]{3}{*}{ RNS } & Pearson Correlation & 1 & $0.321^{* *}$ & $0.362^{\star *}$ & $0.311^{\star *}$ & $0.376^{\star *}$ \\
\hline & Sig. (2-tailed) & & 0.000 & 0.000 & 0.000 & 0.000 \\
\hline & $\mathrm{N}$ & 110 & 110 & 110 & 110 & 110 \\
\hline \multirow[t]{3}{*}{ TND } & Pearson Correlation & $0.321^{* *}$ & 1 & $0.489^{* *}$ & $0.546^{* *}$ & $0.364^{* *}$ \\
\hline & Sig. (2-tailed) & 0.000 & & 0.000 & 0.000 & 0.000 \\
\hline & $\mathrm{N}$ & 110 & 110 & 110 & 110 & 110 \\
\hline \multirow[t]{3}{*}{$\mathrm{PA}$} & Pearson Correlation & $0.362^{* *}$ & $0.489^{* *}$ & 1 & $0.693^{* *}$ & $0.472^{\star *}$ \\
\hline & Sig. (2-tailed) & 0.000 & 000 & & 0.000 & 0.000 \\
\hline & $\mathrm{N}$ & 110 & 110 & 110 & 110 & 110 \\
\hline \multirow[t]{3}{*}{$\mathrm{RM}$} & Pearson Correlation & $0.311^{* *}$ & $0.546^{* *}$ & $0.693^{\star *}$ & 1 & $0.447^{* *}$ \\
\hline & Sig. (2-tailed) & 0.000 & 0.000 & 0.000 & & 0.000 \\
\hline & $\mathrm{N}$ & 110 & 110 & 110 & 110 & 110 \\
\hline \multirow[t]{3}{*}{$\mathrm{OP}$} & Pearson Correlation & $0.376^{* *}$ & $0.364^{* *}$ & $0.472^{\star *}$ & $0.447^{* *}$ & 1 \\
\hline & Sig. (2-tailed) & 0.000 & 0.000 & 0.000 & 0.000 & 0.000 \\
\hline & $\mathrm{N}$ & 110 & 110 & 110 & 110 & 110 \\
\hline
\end{tabular}

${ }^{* *}$ Correlation is significant at the 0.01 level (2-tailed). Source: (Survey Data).

Multiple regression analysis was devised to identify the predictors of POP as conceptualized in the model. To what extent the different types of HRMP can predict POP? To answer this question, inferential statistical technique of Multiple Regression Analysis (MRA) was used. Kerlinger and Lee, (2000) $\left.{ }^{*}\right]$ mentioned that regression analysis is a statistical method that relates one dependent variable to a linear combination of one or more independent variables. Regression identifies the degree of the each independent variable has an impact on dependent variable. For each performance indicator separate data were regressed. Multiple regression analysis calculates multiple correlation coefficients, R2; it is the proportion of variance in dependent variables explained by the independent variables. The contribution of independent variables towards dependent variables is measured by the Beta value and can be explained on the basis of $\mathrm{p}$ or $\mathrm{t}$ value.

Model summary of regression analysis has depicted in Table 8. The generally utilized statistic to evaluate the model fit is $\mathrm{R}^{2}$ which is 1 minus the ratio of residual variability. The adjusted $\mathrm{R}^{2}$, also called the coefficient of multiple determinations, is the percent of the variance in the dependent explained uniquely or jointly by the independent variables. It indicates that $39 \%$ of the changes on POP could be attributed to the combined effect of the predictor variables and consequently hypothesis 2 is supported.

The HRMP (RNS; TND; PA and RM) in the above model revealed the ability to predict POP $\left(R^{2}=0.392\right)$. In this model value of $R^{2}$ denotes that $39.2 \%$ of the 
Table 8. Model summary

\begin{tabular}{cccc}
\hline Model & $\mathbf{R}$ & R Square & Adjusted R Square \\
\hline 1 & $0.588^{\mathrm{a}}$ & 0.392 & 0.331 \\
\hline
\end{tabular}

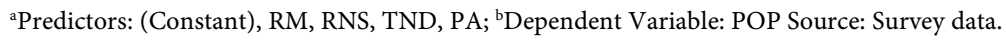

observed variability in POP can be explained by the HRMP explicitly RNS; TND; $\mathrm{PA}$ and RM.

The remaining $60.8 \%$ is not explained which means that the rest $60.8 \%$ of the variation of POP is related to other variables which are not depicted in the model. This variance has highly significant as indicated by the $\mathrm{F}$ value $(\mathrm{F}=15.088$ and $\mathrm{P}<0.01$ ).

Table 9 depicted that the model explains, the most possible combination of predictor variables that could contribute to the relationship with the dependent variable. The regression equation established that taking all factors into account (recruitment \&selection, training \& development, performance appraisal and reward management) constant at zero OP in CFC will be 1.569. The findings presented also indicated that taking all other independent variables at zero, a unit increase in the recruitment \& selection would lead to a 0.237 increase in OP in CFC and a unit increase in the training \& development would lead to a 0.026 increase in the OP in CFC. Further, the findings exhibit that a unit increase in the performance appraisal would lead to a 0.188 increase in the OP in CFC. Additionally, the findings show that a unit increase in reward management would lead to a 0.467 increase in OP in CFC. Overall, training \& development had the least effect on the OP in CFC, followed by performance appraisal. Table 7 also shows that $\mathrm{RM}, \mathrm{RNS}, \mathrm{PA}$ and TND are positively influencing on OP. For RNS the value of $\mathrm{t}$ is $3.41(\mathrm{p}=0.001, \mathrm{p}<0.01)$, for PA the value of $\mathrm{t}$ is $2.833(\mathrm{p}=005, \mathrm{p}<0.01)$, for $\mathrm{RM}$ the value of $\mathrm{t}$ is $3.081(\mathrm{p}=0.004, \mathrm{p}<0.01)$. Thus Hypothesis 3,5 and 6 is supported but Hypothesis 4 is not supported as for TND the $\mathrm{t}$ value is $0.472(\mathrm{p}=$ $0.638, \mathrm{p}>0.01$ ). Hence, it can be concluded that RNS, PA and RM have significant impact on OP but the TND has no significant impact on OP in CFC.

\section{Assessment of Linearity}

Linearity assessment is considered as an implied assumption of all multivariate techniques based on correlation measures of association, inclusive multiple regressions, logistic regression, factor analysis and Structural equation represents only the linear association between the variables (Hair et al., 2009) [45]. Linearity is the assumption that "the mean values of the outcome variable for each increment of the predictor(s) lie along a straight line" (Field, 2009) [47]. Hair et al. (2009) [45] noted that the most usual way to determine the linearity is to inspect the scatter plots of the variables. Hence, any non linear patterns can be identified as spotted away from the straight line. Therefore, this study examined and found the scatter plots with a straight line, representing the linear relationship resulting that nonlinear patterns were absent from the data and positive correlation among the variables (Figure 1). 
Table 9. Coefficients ${ }^{\mathrm{a}}$ model.

\begin{tabular}{|c|c|c|c|c|c|c|}
\hline & \multirow[t]{2}{*}{ Model } & \multirow{2}{*}{$\begin{array}{c}\text { Unstandardized } \\
\text { Coefficients }\end{array}$} & & \multirow{2}{*}{$\begin{array}{c}\text { Standardized } \\
\text { Coefficients }\end{array}$} & \multirow[t]{2}{*}{$\mathrm{t}$} & \multirow[t]{2}{*}{ Sig } \\
\hline & & & Std. Error & & & \\
\hline \multirow[t]{5}{*}{1} & (Constant) & 1.569 & 0.243 & & 6.462 & 0.000 \\
\hline & RNS & 0.237 & 0.070 & 0.284 & 3.413 & 0.001 \\
\hline & TND & 0.026 & 0.054 & 0.044 & 0.472 & 0.638 \\
\hline & $\mathrm{PA}$ & 0.188 & 0.066 & 0.322 & 2.833 & 0.005 \\
\hline & $\mathrm{RM}$ & 0.467 & 0.151 & 0.485 & 3.081 & 0.004 \\
\hline
\end{tabular}

Table 7 Coefficients ${ }^{\mathrm{a}}$; Source: Survey data.

\section{Normal P.P Plot of Regression Standardized Residual Perceived organizational behaviour}

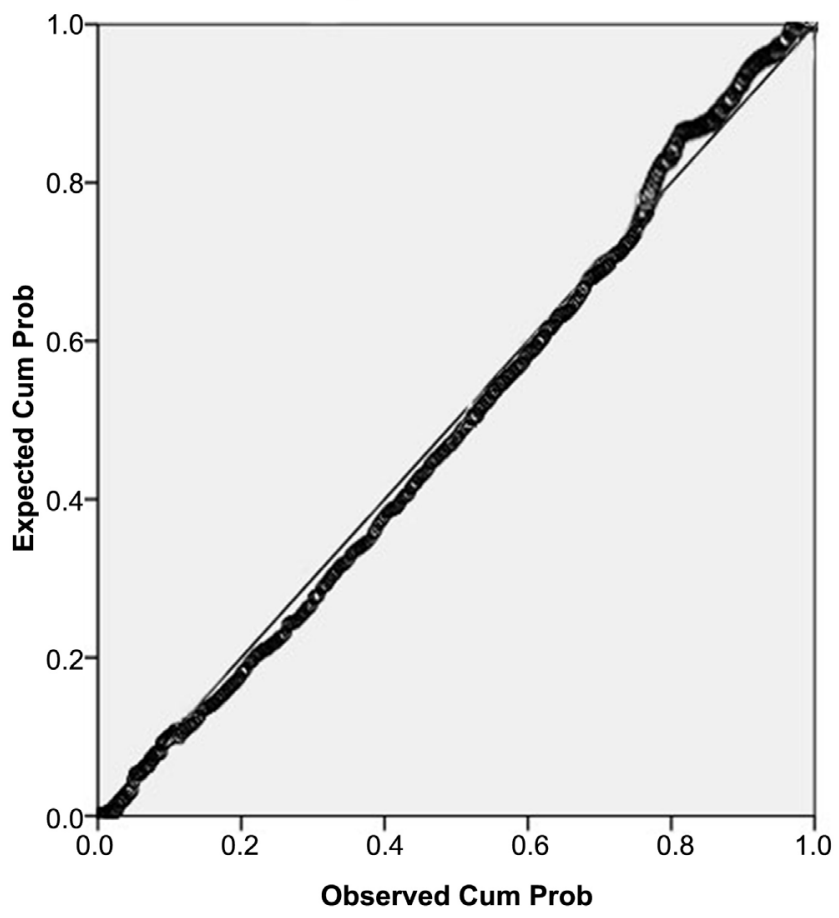

Figure 1. Single regression analyses.

\section{Finding of the Study}

- The first objective of the study is the relationship between HRMP and POP in CFC. The correlation analysis shows that HRMP have a positive relationship with POP. The maximum correlation $(\mathrm{r}=0.463)$ is existed between PA and POP, followed by the association $(r=0.456)$ between RM and POP, RNS and POP $(r=0.372)$ and TND and POP $(r=0.368)$. All the correlations between independents and dependent variable were significant at the 0.01 level. Therefore, Hypothesis 1 of this study was supported.

- The second objective of this study is about the HRM practices and its impact on OP in CFC. The value of R2 denotes that 32.2 percent of the observed va- 
riability in OP can be explained by the HRM practices namely RNS, TND, $\mathrm{PA}$ and RM. The remaining 67.8 percent is not explained and it means that the balance 67.8 percent of the variation of OP and related to other variables which are not mentioned in this model. This variance is highly significant as indicated by the $\mathrm{F}$ value $(\mathrm{F}=15.088$ and $\mathrm{P}=0.000, \mathrm{P}<0.01)$. Therefore, hypothesis 2 is supported.

- The third objective of this study is the measures in order to enhance the OP of CFC. Recruitment and selection practice on its performance the regression analysis of RNS the value of $t$ is $3.41(\mathrm{p}=0.001, \mathrm{p}<0.01)$ shows there is a significant impact on OP of CFC. Therefore hypothesis 3 is supported.

- The fourth objective of this study is the impact of CFC's training and development on its performance. TND the $t$ value is $0.472(\mathrm{p}=0.638, \mathrm{p}>0.01)$. Although there is a relationship between the variables but the relationship was not significant. Therefore Hypothesis 4 is not supported. Hence, the most neglected HRM practices which employees believe that could not help to perform better is, training and development.

- The fifth objective of this study is about the impact of performance appraisal on OP of CFC. PA the value of $t$ is 2.833 ( $p=005, p<0.01$ ) this shows performance appraisal has a significant positive impact on CFC's performance. Therefore, hypothesis 5 is supported.

- The sixth objective of this study is the impact of CFC's reward management practice on its performance. $\mathrm{RM}$ the value of $\mathrm{t}$ is $3.081(\mathrm{p}=0.004, \mathrm{p}<0.01)$ shows the impact is positively significant. Therefore hypothesis 6 is supported.

\section{Conclusion}

The study revealed that the HRMP have a significant impact on POP. It has been found that OP can be attributed to HRMP including recruitment and selection, training and development, performance appraisal and reward management. This study is consistent with Qureshi et al., (2010) [48], Khan, (2010) [49], Huselid (1995) [50], Chang and Chen, (2002) [51]. Based on the results, the researcher concluded that the effectiveness of implementing HRM practices in CFC does indeed have a major impact towards the POP. The findings show that HRMP have an impact of nearly 32.2 percent on POP. Thus, this form of analysis could help organizations to realize and be aware of the importance of HRMP and the need to integrate and align HRMP into the organization's strategic plan. The regression analysis shows that following HRMP seem to have the highest influence on POP during the study period, as recruitment and selection, training and development, performance appraisal, reward management system based on expectancy of employees, comparable with market packages, competency based and performance based, benefits sharing based mechanism, covering both financial and non-financial dimensions, which is positively correlated with POP. Recruitment \& selection, based on well-defined merit and unprejudiced system developed through managerial expert opinions, using standardized test to scru- 
tinize the exact required attitude, skills and knowledge in potential candidates showed notable significant correlation with employee performance and POP. Results were supported by the findings of Singh (2004) [52], Katou, (2008) [53] that identification of the right candidate with right skills to perform the right job for achieving POP is the output of sophisticated selection procedure.

\section{Recommendations}

Human resources being the greatest asset of an organization considered that the employees' knowledge, skills, and abilities are utilized to create and deliver effective services rendered to the organization. Effective recruitment and selection attract the employees with suitable quality, develop the knowledge, skills, and abilities of employees by providing required training and development and retain employees within the organization with proper rewordings. CFC needs to have an effective recruitment and selection policy to promote proper scientific selection of prospective employees. The organization should implement proper selection process as they have different preferences in the candidates. Candidates need to be selected based on requisite skills, knowledge, attitude and qualification using appropriate selection techniques. Besides, appropriate training program for both managerial and non managerial staff should be implemented to continuous improvements. Moreover, a training and development program should be implemented to enhance the abilities and capabilities of employees of CFC. Investing in the improvement of the knowledge and skills of employees would enable the CFC to develop more productive and effective employees. Furthermore, performance appraisal should be guided by the performance management policy. Employee's performance should be assessed based on quantifiable standards and feedback be given to employees on their performance. The appraisal system should be explicitly described specific purpose of the appraisal. Organizations that clearly state the purpose for the appraisal reduce the confusion and ambiguity of the process. Unbiased and accurate evaluation and feedback require clear goals to be established. Performance-related reward system is significant in enhancing performance; hence the organization should implement motivate employees who achieve the set targets. Since HRMP have a significant impact on POP, managers need to implement them in an integrated and coherent manner (Chen et al., 2009; Wickramasinghe and Gamage, 2011 [54]). This study has an addition to earlier research efforts in understanding the relationship between HRMP and POP. The study provides new dimensions in the research of HRM by opening a debate on the importance of HRMP and POP. Statistically significant correlations and regression results were indicated that different HRMP, such as recruitment \& selection, training \& development, performance appraisal and reward management system is significantly related and make positive contributions towards perceived organizational performance.

\section{Suggestions for Future Research Studies}

Future researchers should also consider moderating and or mediating variables 
such as organization culture, organization climate, leadership, labour market, motivation factor and regulatory environment either similar context or different contexts, also consider on different types of HRMP.

\section{Conflicts of Interest}

The authors declare no conflicts of interest regarding the publication of this paper.

\section{References}

[1] Armstrong, M. (2010) Armstrong's Essential Human Resource Management Practice-A Guide People Management. US Kogan Page Limited, London.

[2] Beer, M., Spector, B., Lawrence, P., Quinn Mills, D. and Walton, R. (1984) Managing Human Assets. The Free Press, New York.

[3] Guest, D.E. (1987) Human Resource Management and Industrial Relations. Journal of Management Studies, 24, 503-521. https://doi.org/10.1111/j.1467-6486.1987.tb00460.x

[4] Boxwall, P.F. (2007) The Goals of HRM. In: Boxall, P., Purcell, J. and Wright, P., Eds., Oxford Handbook of Human Resource Management, Oxford University Press, Oxford, 48-67.

[5] Grimshaw, D. and Rubery, J. (2007) Economics and HRM. In: Boxall, P., Purcell, J. and Wright, P., Eds., Oxford Handbook of Human Resource Management, Oxford University Press, Oxford.

[6] Redman, T. and Wilkinson, A. (2001) Contemporary Human Resource Management.

[7] Storey, J. (2007) Human Resource Management: A Critical Text. Cengage Learning EMEA, Andover.

[8] U.S. Army War College (2007) How the Army Runs. U.S. Army War College, Department of the Army, Carlisle.

[9] Noe, R.A., Hollenbeck, J.R., Gerhart, B. and Wright, P.M. (2003) Human Resource Management: Gaining a Competitive Advantage. 4th Edition, McGraw-Hill, Boston.

[10] Dessler, G. (2007) Human Resource Management. 11th Edition, Prentice-Hall, Englewood Cliffs.

[11] Dyer, L. and Holder, G. (1998) Strategic Human Resource Management and Planning. In: Dyer, L., Ed., Human Resource Management. Evolving Roles and Responsibilities, Bureau of National Affairs, Washington DC.

[12] Hamon, T.T. (2003) Organizational Effectiveness as Explained by Social Structure in a Faith-Based Business Network Organization. Unpublished Doctoral Dissertation, Regent University, Virginia Beach.

[13] Delaney, J.T. and Huselid, M.A. (1996) The Impact of Human Resource Management Practices on Perception of Organizational Performance. Academy of Management Journal, 39, 949-969. https://doi.org/10.2307/256718

[14] Bontis, N. (2001) Managing Organizational Knowledge by Diagnosing Intellectual Capital: Framing and Advancing the State of the Field. International Journal of Technology Management, 18, 433-463.

[15] Delery, J. (1998) Issues of Fit in Strategic Human Resource Management: Implica- 
tions for Research. Human Resource Management Review, 8, 289-310. https://doi.org/10.1016/S1053-4822(98)90006-7

[16] Opatha, H. (2009) Human Resource Management: Personnel.

[17] Friedlander, F. and Pickle, H. (1968) Components of Effectiveness in Small Organizations. Administrative Science Quarterly, 13, 289-304. https://doi.org/10.2307/2391456

[18] Richard (2009) Measuring Organizational Performance: Towards Methodological Best Practice. Journal of Management, 35, 718-804. https://doi.org/10.1177/0149206308330560

[19] Thurbin, P.J. (1994) Implementing the Learning Organization: The 17th Days Programme. Pitman Publishing, London.

[20] Subramaniam, C., Shamsudin, F.M. and Ibrahim, H. (2011) Linking Human Resource Practices and Organisational Performance: Evidence from Small and $\mathrm{Me}$ dium Organizations in Malaysia. Journal Pengurusan, 32, 27-37. https://doi.org/10.17576/pengurusan-2011-32-04

[21] De Waal, A. and Frijns, M. (2011) Longitudinal Research into Factors of High Performance: The Follow-Up Case of Nabil Bank. Measuring Business Excellence, 15, 4-19. https://doi.org/10.1108/13683041111113213

[22] Steiss, A.W. (2003) Strategic Management for Public and Non-Profit Organisations. Taylor and Francis Inc., New York.

[23] Guest, D. (2002) Human Resource Management, Corporate Performance and Employee Wellbeing: Building the Worker into HRM. The Journal of Industrial Relations, 44, 335-358. https://doi.org/10.1111/1472-9296.00053

[24] Arsad, M. (2012) Human Resource Management Practices and Organizational Performance: A Study on Administrators in Universiti Teknologi Mara. Unpublished MSc Dissertation, Universiti Utara Malaysia.

[25] Collins, C. and Smith, K. (2006) Knowledge Exchange and Combination: The Role of Human Resource Practices in the Performance of High-Technology Firms. Academy of Management Journal, 49, 544-560. https://doi.org/10.5465/amj.2006.21794671

[26] Kothari, C.R. (2011) Research Methodology: Methods and Techniques. New Age International, New Delhi.

[27] Creswell, J.W., Goodchild, L.F. and Turner, P.P. (1996) Integrated Qualitative and Quantitative Research: Epistemology, History, and Designs. In: Smart, J.C., Ed., Higher Education: Handbook of Theory and Research, Vol. 11, Agathon, New York, 90-136.

[28] Tashakkori, A. and Teddlie, C. (2010) SAGE Handbook of Mixed Methods in Social \& Behavioral Research. SAGE Publications, Inc., Thousand Oaks. https://doi.org/10.4135/9781506335193

[29] Creswell, J.W. (2014) Research Design Qualitative, Quantitative, and Mixed Methods Approaches. 4th Edition, SAGE Publications Thousand Oaks, 131-133.

[30] Moses, A. (2014) Re-Examination of the Limitations Associated with Correlation Research.

[31] Singh, K. (2007) Quantitative Social Research Methods. SAGE Publications India Pvt. Ltd., New Delhi.

[32] Ary, D., Jacobs, L.C. and Sorensen, C. (2006) Introduction to Research in Education. Wadsworth, Belmont. 
[33] Sekaran, U. and Bougie, R. (2016) Research Methods for Business: A Skill-Building Approach. 7th Edition, John Wiley \& Sons, Haddington.

[34] Sekaran, U. and Bougie, R. (2014) Research Methods for Business: A Skill-Building Approach. 6th Edition, John Wiley \& Sons, Haddington.

[35] Sekaran, U. (2000) Research Methods for Business: A Skill Business Approach. John Wiley \& Sons, New York.

[36] Zikmund, W.G., Babin, B.J., Carr, J.C. and Griffin, M. (2010) Business Research Methods. Cengage Learning, Mason.

[37] Bryman, A. and Bell, E. (2015) Business Research Methods. OUP, Oxford.

[38] Tessema, M. and Soeters, J. (2006) Challenges and Prospects of HRM in Developing Countries: Testing the HRM-Performance Link in the Eritrean Civil Service. International Journal of Human Resource Management, 17, 105-186. https://doi.org/10.1080/09585190500366532

[39] Rehman, S. (2012) A Study of Public Sector Organizations with Respect to Recruitment, Job Satisfaction and Retention. Global Business and Management Research: An International Journal, 4, 76.

[40] Dechawatanapaisal, D. and Siengthai, S. (2006) The Impact of Cognitive Dissonance and HR Practices on Learning Work Behavior. Journal of Workplace Learning, 8, 42-54. https://doi.org/10.1108/13665620610641300

[41] Djabatey, E.N. (2012) Recruitment and Selection Practice of Organisation: A Case Study of HFC Bank (GH) Ltd. Master's Thesis, Kwame Nkrumah University, Ghana.

[42] McGhee, et al. (1996) Nature of Learning. McGraw-Hill Book, Boston.

[43] Kim, S.H. and Kim, S. (2016) National Culture and Social Desirability Bias in Measuring Public Service Motivation. Administrative and Society, 48, 444-476. https://doi.org/10.1177/0095399713498749

[44] Mugenda, O.M. and Mugenda, A.G. (1999) Research Methods: Quantitative and Qualitative Approaches. Acts Press, Nairobi.

[45] Hair, J.F., Black, W.C., Babin, B.J. and Anderson, R.E. (2009) Multivariate Data Analysis. 7th Edition, Prentice Hall, Upper Saddle River.

[46] Kline, R.B. (2016) Methodology in the Social Sciences. Principles and Practice of Structural Equation Modelling. 4th Edition, Guilford Press, New York.

[47] Field, A. (2009) Discovering Statistics Using SPSS. 3rd Edition, Sage Publications Ltd., London.

[48] Qureshi, M.T., Ayisha, A., Mohammad, A.K.., Rauf, A.S. and Syed, T.H. (2010) Do Human Resource Management Practices Have an Impact on Financial Performance of Banks? African Journal of Business Management, 4, 1281-1288.

[49] Khan, M.A. (2010) Effects of Human Resource Management Practices on Organizational Performance: An Empirical Study of Oil and Gas Industry in Pakistan. European Journal of Economics, Finance and Administrative Science, 24, 157-175.

[50] Huselid, M.A. (1995) The Impact of Human Resource Management Practices on Turnover, Productivity and Corporate Financial Performance. The Academy of Management Journal, 38, 635-672.

[51] Chang, P.L. and Chen, W.L. (2002) The Effect of Human Resource Practice on Firm Performance: Empirical from High Tech Firms in Taiwan. International Journal of Management, 19, 622-631. https://doi.org/10.2307/256741

[52] Singh, K. (2004) Impact of HR Practices on Perceived Firm Performance in India. 
Asia Pacific Journal of Human Resources, 42, 301-317.

https://doi.org/10.1177/1038411104048170

[53] Katou, A.A. (2008) Measuring the Impact of HRM on Organizational Performance. Journal of Industrial Engineering and Management, 1, 119-142.

https://doi.org/10.3926/jiem.2008.v1n2.p119-142

[54] Wickramasinghe, V. and Gamage, A. (2011) High-Involvement Work Practices, Quality Result and the Role of HR Function: An Exploratory Study of Manufacturing Firms in Sri Lanka. The TQM Journal, 23, 516-530.

https://doi.org/10.1108/17542731111157626 